DOI: https://doi.org/10.5007/1980-3532.2017n17p127

\title{
A doçura da fruta e o fel do conflito laboral: sindicato dos trabalhadores da indústria de conservas de Pelotas (RS)
}

\author{
The sweetness of the fruit and the gall of labor conflict: labor's \\ trade union of canning industry, in the city of Pelotas (RS)
}

\author{
Laura Senna Ferreira \\ Doutora em Sociologia (UFRJ) \\ Universidade Federal de Santa Maria (UFSM) \\ Profa. Departamento de Ciências Sociais (UFSM) \\ laurasennafe@hotmail.com \\ Maria Soledad Etcheverry Orchard \\ Doutora em Sociologia (UFRJ) \\ Universidade Federal de Santa Catarina (UFSC) \\ Profa. Departamento de Sociologia e Ciências Política (UFSC) \\ maria.soledad@terra.com.br
}

\begin{abstract}
Resumo: A indústria de conservas de frutas e hortaliças de Pelotas (RS) já foi a maior empregadora da cidade. Desde fins dos anos 1980 o setor vivenciou o encerramento da maior parte das empresas, como resultado do processo de racionalização tecnológica e gestorial. O desemprego no segmento acarretou numa maior vulnerabilidade econômica e fragilização política dos trabalhadores. Este artigo busca compreender de que maneira as transformações nessa indústria impactaram na atuação do sindicato dos trabalhadores da categoria, considerado um dos mais combativos da região. Trata-se de uma pesquisa realizada a partir de fontes documentais e junto aos trabalhadores, sindicalistas e empresários, com o propósito de entender as razões da intensificação dos conflitos do trabalho e a postura sindical frente aos novos desafios do mundo laboral.
\end{abstract}

Palavras-chave: Trabalho. Sindicato. Indústria de conserva. Desemprego. Assédio.

Abstract: Fruit and vegetable canning industry, in the city of Pelotas (RS), used to be the largest employer in the city. Since the late 1980s, the sector experienced the closure of most companies as a result of technological and managerial rationalization process. Then, unemployment turned into a greater economic vulnerability and political fragilization of workers. The article seeks to understand how the transformations in that industry have impacted on the labor's union performance of the category, which is considered as one of the most combative in the region. It is a research developed from documentary sources along with workers, trade unionists and entrepreneurs to understand the reasons for labor conflicts intensification and the trade union position in the face of new challenges of the job world.

Keywords: Work. Syndicate. Canning industry. Unemployment. Harassment.

Originais recebidos em: 06/10/2017

Aceito para publicação em: 17/04/2018

Este trabalho está licenciado sob uma Licença Creative Commons Atribuição-Uso Não-Comercial-Vedada a criação de obras derivadas 3.0 Unported Licens

Revista Em Debate (UFSC), Florianópolis, volume 17, p. 127-146, 2017. ISSNe 1980-3532 


\section{Introdução}

A indústria de conservas de frutas e hortaliças de Pelotas (RS) já foi a maior empregadora da cidade. O setor dá continuidade a uma tradição produtiva local, associada à agroindústria. $\mathrm{O}$ beneficiamento de alimentos remonta às remotas produções de charque, passando pelo arroz e se destacando com o pêssego. Desde a consolidação do parque industrial do município nos anos 1970, a industrialização do pêssego foi o carro chefe, ao qual se somaram a do figo, abacaxi, aspargo, entre outros.

No passado, as fábricas de conserva eram o destino de boa parte dos trabalhadores que migravam do meio rural para a cidade, bem como dos moradores da periferia. Desde o início o segmento se constituiu de uma força de trabalho composta, sobretudo, por mulheres. Os anos 1980 e 1990 presenciaram o fechamento da maior parte dessas empresas, as quais passaram a operar essencialmente na safra do pêssego e do figo, que acontece entre os meses de novembro a março.

Das 100 empresas que se registrava na década de 1950, restaram 40 nos anos 1980 e somente18 nos fins de 1990. Na década de 2000, apenas havia 12 fábricas de conservas na região, incluindo os municípios de Pelotas, Capão do Leão e Morro Redondo, as quais juntas produzem $98 \%$ da produção de pêssego em calda nacional ${ }^{1}$.

O fechamento das empresas locais está associado ao contexto de reestruturação produtiva, que se traduziu no setor com a adoção de tecnologias e novas formas gestoriais, responsáveis, por um lado, pelo aumento do desemprego e, por outro, pelo enrijecimento do controle sobre o trabalho.

A pressão por produtividade tem intensificado os conflitos do trabalho no segmento, antepondo, para o sindicato do setor, as demandas de atuar num momento no qual se intensifica a racionalização do trabalho e o desemprego, e com ele a própria sustentabilidade do sindicato. A instituição que representa os trabalhadores da alimentação da cidade de Pelotas é conhecida pelo seu caráter militante e combativo. Assim, faz-se pertinente entender a ação dos sindicatos nesses "anos de chumbo", que caracterizaram uma reconversão produtiva perversa, capaz de combinar modernização produtiva e atitude retrógrada do ponto de vista laboral.

Para o presente estudo foram consideradas as entrevistas realizadas com onze trabalhadores, quatro lideranças sindicais e sete empresários, bem como a investigação

\footnotetext{
${ }^{1}$ Fonte: Sindicato dos Doces e Conservas Alimentícias de Pelotas (SINDOCOPEL), 2006.
} 
documental junto aos jornais, livros de denúncia e fichas ocupacionais arquivadas no sindicato dos trabalhadores.

$\mathrm{O}$ artigo está dividido da seguinte maneira. Num primeiro momento apresenta-se o perfil do sindicato dos trabalhadores. A seguir se considera os dilemas enfrentados pela instituição, a partir do desemprego e da intensificação dos conflitos laborais. Por fim, analisam-se a relação entre os processos de racionalização e os conflitos do trabalho à luz da literatura sociológica que busca compreender as novas dinâmicas do mundo do trabalho.

\section{Sindicato dos trabalhadores das conservas}

O Sindicato das Indústrias e Cooperativas da Alimentação (STICAP) surgiu, em 1974, da reunião de várias categorias do ramo alimentício da região de Pelotas: conservas, engenho de arroz, panificação, frigoríficos, laticínios, bebidas, fumo, café, óleo e moinhos, totalizando dez categorias. São quatro datas bases diferentes e os acordos coletivos são construídos junto a dez sindicatos patronais. O STICAP filiou-se à Central Única dos Trabalhadores (CUT) em 1985. Em 1989 a chapa cutista "Nossa Luta" foi vitoriosa, apresentando uma postura mais combativa na forma de enfrentamento com a classe patronal ${ }^{2}$.

A diretoria sindical é composta por vinte e quatro membros distribuídos entre a presidência e dez secretarias. A eleição é feita a cada três anos. Esse sindicato é reconhecido por ser um dos mais combativos da região. De acordo com seu presidente (entrevista, 2007),

\footnotetext{
Nós temos como princípios a luta de classe e a defesa dos trabalhadores. Nós não temos ilusão sobre a relação capital e trabalho, a gente sabe, para nós, na nossa visão de mundo do trabalho, não existe conciliação, existe negociações, mas a gente sabe que nós nunca vamos atingir uma harmonia com o capital [...] Banco de hora, redução de salários, esse tipo de coisa nós nem discutimos, a gente vai para o pau direto.
}

O STICAP atua junto a outros sindicatos, associações de bairro e movimentos sociais, como Movimento dos Sem Terra (MST) e o Movimento dos Trabalhadores Desempregados (MTD). O membro mais antigo da diretoria relata um pouco da sua experiência de quase três décadas de atuação sindical,

\footnotetext{
${ }^{2}$ No período (ano de 1990), ocorreu o assassinato do sindicalista Daltro dos Santos, pelo proprietário de uma padaria de Pelotas. Fonte: Nossa Luta (acervo pessoal de ex-jornalista do STICAP).

Revista Em Debate (UFSC), Florianópolis, volume 17, p. 127-146, 2017. ISSNe 1980-3532
} 
[...] o nosso sindicato sempre foi, desde que eu tô no sindicato, desde 1980, pela defesa intransigente dos direitos dos trabalhadores, não abre mão disso, independente de governo, o trabalhador sempre em primeiro lugar. $\mathrm{O}$ sindicato não tem nada a ver com política partidária [...] não abre mão do direito à greve quando ela tem que ser feita, que esse é o instrumento que os trabalhadores têm para se contrapor ao capital. Durante esses anos todos, o sindicato da alimentação sempre teve na linha de frente no movimento sindical, tanto a nível regional, local, como no Estado. Na categoria da alimentação o nosso sindicato sempre foi uma referência até para sindicatos de outras categorias (Diretor sindical, entrevista, 2007).

Além da disputa política, o sindicato disponibiliza assistências médica, jurídica e odontológica aos trabalhadores da categoria, tanto aos sócios, quanto aos não sócios. $\mathrm{O}$ STICAP produz um jornal mensal que é entregue nas empresas e disponibilizado em uma página na internet, no qual são tratados: assuntos das categorias, denúncias, dúvidas sobre direitos etc.

O STICAP é filiado à $\mathrm{CUT}^{3}$, mas os membros da diretoria fazem severas críticas à Central, por ter estado muito atrelada ao governo. Optaram por continuar filiados por acreditar que a instituição ainda é uma referência para os trabalhadores, mas decidiram não pagar mais as contribuições: “[...] de uns anos para cá não é a mesma central [...] tu não vê mais uma greve geral puxada pela CUT. Uma greve em defesa da soberania nacional, pelas 40 horas semanais, o não pagamento da dívida externa" (Membro mais antigo da diretoria do STICAP, entrevista, 2007).

O sindicato tem se dedicado à questão da formação dos trabalhadores ${ }^{4}$. Também, com o intuito de diversificar sua atuação, buscou participar do Conselho Ambiental de Pelotas, do Conselho da Saúde e de discussões sobre o Plano Diretor da cidade, além de ter dois programas em uma rádio comunitária. Em 1996 um dos membros do sindicato foi candidato a vice-prefeito ${ }^{5}$ e, no governo do Partido dos Trabalhadores (PT) no

\footnotetext{
${ }^{3}$ Em relação ao movimento internacional, a organização que os representa - União Internacional dos Trabalhadores da Alimentação (UITA) -, com sede em Genebra, está, no Brasil, articulada com a Confederação dos Trabalhadores da Alimentação (CONTAC), atrelada à CUT.

${ }^{4}$ Durante o período de pesquisa no STICAP, um dos sindicalistas estava realizando curso de formação para delegados e diretores. Entre os temas de estudo verificavam-se: história do modo de produção capitalista; troca de Mercadorias; mais-valia; força de trabalho; taylorismo e fordismo; flexibilização; globalização e as mudanças no mundo do trabalho. Fonte: Programa de Formação Sindical. Federação dos Trabalhadores nas Indústrias da Alimentação do Estado do Rio Grande do Sul. Círculo de Estudos nível II. As mudanças no mundo do trabalho, 2007. Em outro material utilizado na formação, discutiase o mundo do trabalho a partir de depoimentos sobre educação e empregabilidade. Fonte: STICAPDVD-Trabalho e Formação em Movimento, 2006.

${ }^{5}$ Outra ação representativa dessa busca por novas práticas sindicais foi quando, em 1999, o sindicato formou a segunda turma do Projeto Integrar, o qual busca requalificar trabalhadores desempregados ou prestes a perder o emprego. A iniciativa ocorreu em várias cidades, com verbas do Fundo de Amparo aos Trabalhadores (FAT). Fonte: Nossa Luta, 1999.
}

Revista Em Debate (UFSC), Florianópolis, volume 17, p. 127-146, 2017. ISSNe 1980-3532 
município (2001-2004), um dos diretores sindicais foi deslocado para uma secretaria do governo.

Nos anos 1990 criou a Secretaria da Mulher e organizou o Grupo da LER, que se reúne periodicamente para terapia junto aos trabalhadores que sofrem dessa doença ${ }^{6}$. Os problemas da saúde dos trabalhadores, o desemprego na região e a redução da arrecadação sindical tem sido o cerne da preocupação da diretoria: "[...] com as empresas que fecharam, e com as que tão fechando, o sindicato reduziu muito a arrecadação, então não dá pra fazer muita coisa, a gente faz o mais grosso [...] a gente está apavorado porque tem cada vez mais demissões" (diretor sindical, entrevista, 2007).

\section{Sindicato e a crise do setor conserveiro}

A indústria de conservas da região Sul já foi o ramo da alimentação que mais empregou trabalhadores. Antes do fechamento da maioria das empresas nos anos 1980, não havia mão de obra suficiente para atender a demanda, as empresas buscavam pessoas de fora da cidade para a safra ${ }^{7}$. Sobre essa época, o vice-presidente do STICAP (entrevista, 2007) relata:

[...] uns anos atrás, quando existia praticamente o pleno emprego nas conservas, o sindicato fazia grandes assembleias. A partir do momento que as indústrias começaram a fechar, ou se modernizar com novas tecnologias, e os trabalhadores começaram a perder seus postos de trabalho, isso gerou um pouco de afastamento do trabalhador, mais pelo medo, pela repressão, as empresas vão fechar, o sindicato exige demais da empresa, como se fosse o sindicato que fizesse uma empresa fechar. O que é uma grande mentira, porque mais de uma vez o sindicato viajou junto com os empresários pra cobrar do governo políticas pro setor de conservas [...] sobretaxas de importação pra não prejudicar o pêssego daqui.

As novas tecnologias foram capazes de reduzir muito o número de trabalhadores, principalmente, mulheres ${ }^{8}$. Segundo um dos diretores sindicais, essas

\footnotetext{
${ }^{6}$ Esteve-se presente em um dos encontros do Grupo da LER coordenado por uma psicóloga que incorpora técnicas de medicina chinesa durante a terapia. A psicóloga considera o grupo importante para melhorar o astral e deixar as pessoas mais alegres. Ali, conversam, contam piada e divertem-se. O grupo ainda serve como espaço de troca de informações. Observação no local, STICAP, julho, 2007.

${ }^{7}$ Média do número de trabalhadores da categoria das conservas na safra: 1980 - 15.000 trabalhadores; 1990 - 7.500; 2000 - 4.000; 2.006 - 3.155. Em 2006/2007 na safra, 3.155 safrista (75,72\%); na entressafra, $766(24,28 \%)$. Associados ao sindicato, $1.063(33,69 \%)$. Todas as categorias de trabalhadores do STICAP, estimativa 2006/07, 5000 trabalhadores. Safristas representam $63 \%$ e efetivos das conservas 15,32\%. Fonte: STICAP, 2007.

${ }^{8}$ Conforme pesquisa realizada pela FEE, a produção de alimentos, ao longo dos anos, apresenta-se como espaço que concentra mão de obra feminina. No ramo das conservas, atividade sazonal comum às

Revista Em Debate (UFSC), Florianópolis, volume 17, p. 127-146, 2017. ISSNe 1980-3532
} 
empresas modernizaram-se, nos anos 1990, com os incentivos fiscais. O governador Antônio Britto (PMDB) criou o PRIM, um programa que destinava recursos para investimentos em tecnologia ${ }^{9}$. Alguns empreendedores investiram e modernizaram seus negócios, outros pegaram o dinheiro para pagar a demissão dos trabalhadores ${ }^{10}$.

O vice-presidente do STICAP considera que antes da intensificação do desemprego no segmento, não tinham como panfletar com duas pessoas na frente das fábricas, alguns trabalhadores não conseguiam pegar os panfletos e o jornal ${ }^{11}$. Todavia, desde os anos 1990, verificam-se mudanças:

[...] as conservas, a cada ano elas vem procurando formas de evoluir, de fazer com que a modernização diminua o custo para eles, tire trabalhador do mercado. Os empresários na verdade querem o quê? Diminuir gastos com a mão de obra. Pagar os outros impostos eles pagam, até porque dão um jeito de sonegar. Mas sonegar impostos com mão de obra não tem como.

A coordenadora da Secretaria da Mulher (entrevista, 2007), antes de entrar para o sindicato, conta que na época em que se empregava muita gente, as empresas andavam com microfone na rua, buscavam pessoal em várias cidades de ônibus: “[...] antigamente dava emprego pra muita gente, e era tudo manual, as mulheres ficavam com o pulso inchado do descaroçador que usavam pra descaroçar o pêssego, era por produção, elas ganhavam também uma comissão se passava”. Todavia, a partir dos anos 1990, muda a dinâmica do emprego no setor:

[...] precisam de menos gente do que precisavam na década de 70 para produzir o mesmo número de latas [...] o sistema é muito eficiente. O que eu acho que não é ruim, porque tu tem condições de dar emprego pra todos, tu reduz a jornada. A tecnologia, ela veio pra beneficiar, a pessoa se rala muito menos (presidente do STICAP, entrevista, 2007).

Os sindicalistas são unânimes quando se referem às consequências do desemprego para a região e quanto ao fato dele ter deixado os trabalhadores em uma

mulheres, as transformações dos últimos anos atingiram mais a força de trabalho feminina. As indústrias de conservas, que eram as que mais empregavam na região de meados de 1990 até 2000, de 12.0001 safristas registradas, as fábricas registram 5.000. Fonte: Indicadores Econômicos FEE, Porto Alegre, v.30, n.2, 2002.

${ }^{9}$ A lei do PRIM, criada pelo governador Britto (PMDB) em 1996, estipulava um retorno de $75 \%$ do ICMS para o setor. No Art. $8^{\circ}$ II, consta que o setor, para receber os incentivos, deveria estar comprometido em "gerar emprego". Fonte: Assembleia Legislativa.website:www.al.rs.gov.br (acesso, junho de 2007).

${ }^{10}$ Em nota do Jornal Nossa Luta: "Mais uma vez a [...] parte para demitir um número grande de trabalhadores com dinheiro público, concedido pelo governo Britto, através do PRIM" (Dezembro, 1998).

${ }^{11} \mathrm{O}$ vereador entrevistado (entrevista, 2007) também conta sobre esse tempo no qual não havia mão de obra suficiente na cidade. Segundo ele, haviam alojamentos que abrigavam trabalhadores trazidos de fora do município. Um carro de som passava nas ruas chamando o pessoal e esses entravam no caminhão para irem em direção às fábricas.

Revista Em Debate (UFSC), Florianópolis, volume 17, p. 127-146, 2017. ISSNe 1980-3532 
condição ainda mais vulnerável: "A nossa cidade é composta por a maioria das pessoas que vem do interior, que migrou pra cá na década de 70 e 80 [...] quando essas empresas que empregavam muitas pessoas fecham [...] aí tu entra na questão do subemprego, na marginalização" (presidente do STICAP, entrevista, 2007).

[...] na época de grande massa dos trabalhadores da conserva, os trabalhadores não se deixavam ser humilhados. Não tá bom aqui, então eu vou pra outra empresa, trabalhava um mês numa empresa, outro mês em outra, porque sabiam que tinha empresa em tudo que era canto da cidade. Hoje não, humilham os trabalhadores, muitas vezes terminam atrasando salários [...] os trabalhadores perderam muito com essa falta de serviço (vicepresidente, entrevista, 2007).

A questão do desemprego no setor foi colocada em pauta pelo STICAP nas reuniões que participou junto à Cadeia Produtiva do setor $(\mathrm{CAFH})^{12}$. Quando participavam da CAFH, contribuíram, em fins de 1990, para instituir o processo antidumping contra a entrada do pêssego grego. Deixaram de ir às reuniões da Cadeia por não verem contrapartida para os trabalhadores.

A participação do STICAP na Cadeia não teve aproveitamento nenhum, muita reunião e pouca ação [...] toda vez que tu tocava no nome dos trabalhadores, os empresários tiravam o corpo fora, achavam que primeiro tinha que tratar do pêssego em si, das empresas em si, como se os trabalhadores não fizessem parte disso. Essa discussão de Cadeia Produtiva, o que é? É um grupo de empresários sentados, discutindo o seguinte: o que é que nós vamos fazer pra lucrar (vice-presidente, entrevista, 2007).

O STICAP manifestou para os empresários que somente participaria da Cadeia se fosse possível discutir redução de jornada, melhores condições de trabalho e a questão de não demitir trabalhadores. Quando a diretoria do STICAP participava da Cadeia foram ao Chile para ver como era produzido e industrializado o pêssego. Afirma-se que, nesse país, tanto os trabalhadores rurais, quanto os fabris, estão ainda mais desassistidos que no Brasil, e o sindicato deles é de pouco enfrentamento. "Talvez por isso o pêssego deles consiga ter bem mais espaço no mercado do que o nosso [...] no Chile os trabalhadores estão sem direito trabalhista algum. A gente ainda tá numa situação bem melhor. Apesar de eu achar que é horrorosa" (vice-presidente do STICAP, entrevista, 2007).

\footnotetext{
${ }^{12}$ Em 1998, o Jornal Nossa Luta registra a participação do presidente do STICAP no $2^{\circ}$ Seminário da Cadeia Produtiva das Conservas: "Pela primeira vez reuniram-se, num mesmo evento, trabalhadores da alimentação, produtores rurais, sindicato rural, patronal das conservas da alimentação, EMATER, EMBRAPA e universidade [...] As entidades debateram alternativa para o setor, que enfrenta dificuldades. Uma comissão vai acompanhar proposta junto ao governo do Estado" (Dezembro, 1998).
} 


\section{Sindicato e o caráter conflitivo do setor}

Os sindicalistas dizem que as negociações sempre foram muito difíceis no setor conserveiro, o piso salarial da categoria é o menor do ramo da alimentação e a utilização do contrato safrista flexibiliza as relações. Em alguns casos, os trabalhadores ficam seis meses e são demitidos sem direito a férias, fundo de garantia e aviso prévio. Muitas vezes as empresas demitem, esperam alguns meses e contratam os mesmos trabalhadores. A regulamentação desse tipo de contrato se deu no governo do presidente Fernando Henrique (PSDB, 1995-2002).

A condição de safrista dificulta a organização coletiva desses trabalhadores ${ }^{13}$, sendo essa a categoria mais afastada do sindicato. Todavia, no passado, houve muitos diretores sindicais no setor conserveiro. Embora pouco presente no sindicato, esse setor, na década de 1980, foi o que mais moveu ações trabalhistas na categoria da alimentação ${ }^{14}$. Existem processos pendentes movidos contra empresas que fecharam e processos correndo contra algumas ainda em funcionamento ${ }^{15}$.

Um desses processos se refere à questão da insalubridade, movido contra a fábrica na qual houve uma greve pelo fato da empresa pretender retirar esse direito. Conforme a diretoria do sindicato, essa greve foi solicitada pelos próprios trabalhadores, dos 300 empregados efetivos, 80 participaram, muitos deles demitidos depois ${ }^{16}$.

Muitas greves já foram realizadas no setor. Uma dessas ocorreu no início de 1990, durante a safra: “[...] uma fábrica de conserva, em plena safra do pêssego, tu parando ela um dia é um horror. Na safra, tem na frente da fábrica 40, 50 caminhão pra descarregar, se paralisar não descarrega, e a fruta é perecível, como já tá entregue pra eles, eles são responsáveis, vão ter que pagar” (presidente STICAP, 2007).

\footnotetext{
${ }^{13}$ Segundo o sindicalista, a maioria dos trabalhadores nos anos 1980 era de origem rural. Hoje são mais urbanos, com a "mente mais aberta". Mas, em compensação, há mais medo de demissão (informante). Verifica-se que em 2002 93,72\% da população de Pelotas residia no meio urbano. Fonte: FEE, 2002.

${ }^{14} \mathrm{Em}$ um desses processos coletivos, movido contra uma das maiores empresas da cidade, com base no art.195 da CLT, o sindicato denunciou a existência de insalubridade e periculosidade nas instalações da empresa. De acordo com os laudos do processo, os empregados eram submetidos a situações precárias: insuficiência de iluminação, ruídos acima dos níveis permitidos, calor excessivo, umidade, manipulação de óleo e graxas minerais. Apresentando o laudo pericial e confirmada a existência das referidas condições insalubres, a reclamada foi condenada a pagar os adicionais devidos. Nessa ação, estavam incluídos 341 trabalhadores. Fonte: Processo $n^{\circ}$ 4395/88. Poder judiciário. Justiça do trabalho. Junta de Conciliação e Julgamento. Ano: 1989/90/91. Segundo um dos membros da diretoria do STICAP (entrevista, 2007), até 1988, moviam-se muitas ações coletivas e tinham-se grandes laudos. Nos anos mais recentes, como as ações são individuais, os peritos fazem laudo apenas da função do reclamante.

${ }^{15}$ Processos trabalhistas (coletivos) conservas: 1980 - 26 processos; 1990-35; 2000- 11; 2007- 6.

Em 1980/90, os processos foram principalmente por causa de insalubridade. A partir de 2000, esses processos foram de ação de cumprimento de pagamento de verbas rescisórias. Fonte: STICAP.

${ }^{16}$ Fonte: Nossa Luta, abril, 2007.
} 
A coordenadora da Secretaria da Mulher aponta que um dos maiores problemas nesse setor, o mais difícil de lidar, por que não se faz greve por esse motivo, é o assédio sexual e moral a que estão submetidas as trabalhadoras. A Secretaria recebe muitas denúncias nesse sentido e o sindicato tem dificuldade de agir. Publicam as situações no jornal, vão a empresa falar com o proprietário, mas é uma situação que as mulheres nem sempre denunciam. O Ministério do Trabalho fiscaliza se as empresas estão assinando a carteira de trabalho e cumprindo suas obrigações legais, e deixa os demais compromissos a serem regulados pelo sindicato ${ }^{17}$.

[...] chega na safra, tem moça bonitinha que vai trabalhar, o encarregado encosta do lado e fica de cantadinha, de piadinha, né? As moças precisam trabalhar e ficam quietas. E eles dizem: se tu ficar comigo te boto de efetiva, se sair comigo eu te boto num setor mais mole, te boto num serviço melhor. As velhas reclamam também: porque eu sou velha, eu sou feia, eu sou gorda, pra mim, eu já sou tratada tipo animal, com palavrões, xingadas, eles botam num serviço barra pesada. E não só o assédio sexual, o assédio moral, o assédio verbal, todo tipo de assédio (coordenadora da Secretaria da Mulher, entrevista, 2007).

Situações de mulheres submetidas à condição de violência são relatadas, inclusive, o caso de uma moça estuprada no banheiro de uma das fábricas que teve medo de denunciar o ocorrido. A maioria das chefias são homens, em um setor que mais de $90 \%$ da mão de obra é feminina.

Conforme os sindicalistas, os trabalhadores são desestimulados de procurar o sindicato. Mesmo os cipeiros (Comissão Interna de Prevenção de Acidente/CIPA), ou aqueles que tem estabilidade por causa de acidente. A empresa tira-os dos setores estratégicos e coloca-os nas piores funções se souber que entraram em contato com o sindicato.

Para o vice-presidente (entrevista, 2007), a baixa participação sindical dos trabalhadores desse setor também está relacionada a sua própria condição de trabalho: "passar o dia inteiro em pé, no mesmo serviço, a mesma coisa, nem máquina resiste, acaba quebrando [...] essa aproximação deles virem no sindicato é difícil, termina que no fim do dia eles tão exaustos".

\footnotetext{
${ }^{17}$ Entre as denúncias encaminhadas ao Ministério do Trabalho, a partir de 2000, constatamos um caso no qual a empresa foi denunciada por estar começando a safra com 50 pessoas sem carteira, salário abaixo do piso da categoria, horas extras em excesso, não fornecimento de EPI necessário, não entrega de vale transporte e não fornecimento ao sindicato da relação de trabalhadores. Denúncia contra uma escola Federal em Pelotas que possuía, em suas dependências, fábrica com vários trabalhadores recebendo salário que não chegavam nem a ser o da convenção coletiva, entre outras denúncias. Fonte: Denúncias encaminhada a MTE - Delegacia Regional do Trabalho (RS).
} 
As severidade de tratamento a que são submetidos os trabalhadores é uma constante nos depoimentos: “[...] a chefia não tem educação para tratar as pessoas, tratam como bichos, humilham as pessoas, e as pessoas tem que ficar quieta, né? Se reclamar vão pra rua [...] os trabalhadores não têm opção, eles dizem: se tu não quer, tem cinquenta esperando lá na frente" (coordenadora da Secretaria da Mulher, 2007).

Segundo sindicalista (diretor sindical, entrevista, 2007), esse setor é o mais precário do ramo da alimentação: “[...] há empresas que tem benefício para afastar os trabalhadores do sindicato. Mas a conserva tá tão ruim que nem isso tem" ${ }^{\text {. }}$.

\section{Conjunções do universo laboral no setor conserveiro}

Pesquisaram-se alguns espaços de atuação do sindicato junto aos trabalhadores das conservas. Não haviam documentos específicos direcionados apenas a essa categoria, então, analisaram-se as matérias do Jornal Nossa Luta, o livro de denúncias e as fichas ocupacionais, a partir do início dos anos 1990.

As fichas ocupacionais resultaram de uma nova política na área da saúde. A ideia era ter um acompanhamento da história ocupacional de trabalhadores das diferentes categorias da alimentação. Consultaram-se aquelas relacionadas ao setor conserveiro, de 1991 a 1999, período que foram efetuados os cadastros. A análise de 72 fichas permitiu observar aspectos das condições de trabalho.

Conforme os prontuários médicos anexados a essas fichas, verificam-se: pacientes que se queixavam de dores nas pernas (por ficarem muito tempo parados em pé na esteira), dores na coluna (por carregarem muito peso), sinusite (ligado à ocupação em ambientes úmidos e poluídos), cefaleia (associada ao manuseio de cloro), LER (devido os movimentos repetitivos) e neurose obsessiva (adquirida depois que começam a trabalhar na fábrica) e problemas de gastrite, "[senti] dor no estômago... come poucas vezes no dia e a comida é requentada [...] só tem um intervalo para as refeições numa jornada de 8 horas" (prontuário, 1991).

Das fichas ocupacionais, destacam-se as funções mais comuns desses trabalhadores: serviços gerais, os quais incluem trabalhar na recravadeira, enlatamento, mecânico de manutenção, caldeirista, descascamento, balanceira, descaroçamento,

\footnotetext{
${ }^{18}$ Conforme um dos entrevistados, "As indústrias de outros municípios fazem pracinha, tem creche, dão alimento a comunidade e tal, aqui não tem nada disso [...] então, reduziu a mão de obra, melhorou, talvez, a rentabilidade, e não tem nada entregue a sociedade como forma de recompensa" (Pesquisador da EMBRAPA. R.O).
} 
raspagem de frutas, limpeza, auxiliar de caldeira, segurança, descarregador de caminhão, carregador de bacias e caixas, abastecimento de pêssego nas máquinas, rotulagem, limpeza do pêssego, carimbo de latas, colocação de latas nas caixas, entre outras.

Em praticamente todas as fichas os trabalhadores se referem ao excesso de jornada, as faltas de horário de lanche e intervalo. A grande maioria declarou ficar exposto a alguma ou a quase todas as condições de excesso de cargas físicas, químicas, fisiológicas e psicológicas. Expuseram-se situações de acidentes: cortes nas mãos, queimaduras nos tachos de doces e até pingos de soda nos olhos (Ficha, ano1991).

Casos semelhantes foram verificados no livro de denúncias do sindicato, adotado a partir de 1992, para registrar as queixas dos trabalhadores que telefonam ou vão ao sindicato. Todas as fábricas foram alguma ou muitas vezes referidas. Quando denunciam, os operários pedem providência do sindicato, solicitam paralisações e greves. Das reclamações destacam-se: trabalhadores sem carteira assinada; atraso de salários; não pagamentos de horas-extras, auxílio escolar, abono família, diferença de dissídio, $13^{\circ}$ salário e verbas rescisórias. Há um caso de funcionário que batia cartão ponto de todos os trabalhadores às $18 \mathrm{~h}$, enquanto esses continuavam trabalhando. Também, situações nas quais as horas-extras iam para o Banco de Horas. Uma trabalhadora foi pessoalmente ao sindicato dizer que eles estavam fazendo 16 horas e que a empresa fechava o portão para ninguém sair. Há queixas de excesso de jornada, mesmo em épocas inusitadas, como por exemplo, os encarregados "fecharam o portão na véspera de Natal para obrigar os trabalhadores a fazerem horas-extras" (dezembro, 1996). Algumas trocam por folga na segunda, o trabalho realizado no domingo.

As empresas são denunciadas por não pagar os funcionários quando esses deixam de trabalhar por falta de fruta. E há denúncias de fábricas que demitiram mulheres por estarem grávidas. Em 2003, o livro registra queixa realizada por estudante que fez estágio em uma das empresas, e a acusa de estar usando excesso de produtos tóxicos nas conservas (março, 2003). Além disso, são frequentes as denúncias de trabalhadoras ofendidas por encarregados e proprietários, "a patroa tem ameaçado os empregados. E, pelo denunciante, a mesma anda armada dentro da empresa" (abril, 1997). Sobre o encarregado, “[...] humilha as trabalhadoras, uma delas teve alta de pressão, e foi parar no pronto socorro" (novembro, 1998). Eles, "tratam os trabalhadores como animais, aos gritos, com palavrões e empurrões” (julho, 1999). As operárias reclamaram o não pagamento de horas-extras e o supervisor "mandou elas calarem a Revista Em Debate (UFSC), Florianópolis, volume 17, p. 127-146, 2017. ISSNe 1980-3532 
boca, porque a porteira está cheia de gente pra trabalhar" (dezembro, 2002). Denunciase que em uma das fábricas "têm uma encarregada que humilha e chama o pessoal de vaca, atirou até um caixa de pêssego por cima das mulheres" (dezembro, 2004). O livro também registra situações de assédio como, por exemplo, “o encarregado [...] continua com atitudes inconvenientes. Está passando cantada nas mulheres” (janeiro, 2000). Outra declaração, “quer agarrar as gurias novas numa peça lá no depósito [...] Diz a elas que vai lhes conseguir um trabalho melhor" (dezembro, 2003).

Outro espaço no qual aparecem questões relacionadas aos trabalhadores do setor conserveiro é no Jornal Nossa Luta do STICAP. Fizeram-se consulta a alguns boletins anteriores e analisaram-se notas dos jornais, a partir de 1990, que se referiam aos trabalhadores das conservas ${ }^{19}$. Notas essas decorrentes das denúncias e das observações feitas a partir das visitas às empresas. Ao longo dos anos as queixas repetem-se. A partir de 2000, entram poucos fatos novos, mas as doenças ocupacionais passaram a ser mais frequentes. A propósito da continuidade dos problemas vividos pelos trabalhadores, o Jornal do STICAP registra:

[...] mais uma safra de conservas de pêssego está em andamento e com ela, infelizmente, se repetem problemas históricos com os direitos dos trabalhadores safristas [...] atitudes exploradoras e irregulares, como excesso de jornada de trabalho, sonegação de horas-extras, ritmo acelerado de trabalho, ambientes ruins de trabalho, entre outros tantos problemas, como até a falta de respeito por parte de alguns patrões e encarregados (janeiro, 2007).

\section{Conflitos do cotidiano laboral}

Os conflitos que ocorrem no interior da empresa se expressam, em grande medida, nas tensões que envolvem o controle do tempo, essencialmente, as tentativas de discipliná-lo e torná-lo produtivo.

A esse respeito um dos empresários reflete sobre sua intenção de reduzir pela metade o número de empregados, afim de evitar problemas de indisciplina.

[...] o cara que tá no descaroçamento manual, ele trabalha por tarefa [...] quando ele fez a produção e atingiu o mínimo, aí ele sai, dá volta, e eu tenho que tá na mão dele, não tenho máquina, tenho que fechar o olho e é aquele

\footnotetext{
${ }^{19} \mathrm{O}$ sindicato, no momento da pesquisa, não tinha esses jornais arquivados. Isso estava sendo realizado por estudantes e historiadores do IMA (Instituto Mario Alves). Esse material encontrava-se disperso, por isso, nem todos os jornais desse período puderam ser consultados. Para tentar reduzir as lacunas, se recorreu aos arquivos pessoais de algumas pessoas, como o do ex-jornalista do STICAP. Anteriormente a 1989 não existiam jornais, na década de 1970 eram proibidos e em 1980 a diretoria não se dedicava a isso. A partir de 1990 é que o jornal passa a ser considerado um recurso de maior aproximação junto aos trabalhadores.
} 
negócio, eu faço de conta que não vi, ele faz de conta que tá trabalhando, isso é um inferno, então, tem que ter equipamento, por isso que todo mundo bota equipamento (empresário, entrevista, 2007).

No que toca aos conflitos do trabalho, um dos ex-industriais, empresário da década de 1950 até 1996, avalia que a relação da empresa com os trabalhadores sempre foi harmônica, ao contrário da relação com o sindicato. A seguir, destaca-se um longo excerto da entrevista por considerá-lo expressivo dos aspectos conflitivos envolvendo o trabalho:

[...] infelizmente o nosso sistema trabalhista aqui no Brasil é um desastre, não vou falar em outros setores porque não conheço, mas no setor de conserva era um desastre. Eu tinha permanentemente um diretor do sindicato dos trabalhadores dentro da fábrica, permanentemente, até o mês da minha falência, simplesmente pra anarquizar dentro da empresa [...] escolhiam um cara, alternavam um cara dentro do sindicato, e botavam de empregado lá. A gente contratava um empregado, sem saber quem tá botando, de repente ele vai e diz, eu sou efetivo aqui dentro e você não pode me botar na rua. Eles vinham só para anarquizar, em primeiro lugar não trabalhavam, em segundo lugar anarquizavam [...] mandavam os outros anarquizar tudo que pudessem no serviço, eu tive casos de reclamações de acharem luvas dentro das latas de compotas, parafusos de máquinas dentro das latas de compotas, e como é que eu ia saber? E vinha reclamação do consumidor, então desastre de tudo que é maneira, fazer a máquina trabalhar mal, falta de lubrificação, coisas terríveis, não dá pra falar [...] Eu não me queixo do trabalhador de Pelotas, o trabalhador é boa gente, eu não tive problema com o trabalhador, tive problema com sindicato, isso sim. Eu tenho, não vou usar o termo ódio, porque é muito forte, eu tenho desprezo por esse sindicato aqui de Pelotas. Só tenho glória a dizer do trabalhador, a gente sabe que tem as ovelhas negras, em qualquer indústria que você tiver, você vai ter gente que tudo é capaz de fazer pra que feche aquela indústria, é da índole. No tempo que eu estudei eu não conhecia o DNA, hoje eu conheço o DNA, mas infelizmente, a gente não pode tirar amostra do sangue do cara pra saber, se eu pudesse eu fazia isso [...] eu só posso dizer o seguinte, não é que eu seja contra o sindicato dos trabalhadores, eu fui presidente do sindicato dos patrões, o sindicato não tem culpa, é de quem tá lá [...] despachei um funcionário com estabilidade, sabendo que eu ia sofrer as maiores consequências, mas pensei, eu vou despachar, veio o sindicato inteiro contra mim, contra a fábrica. Eu disse pra ele, tu vem comer no cocho que tu derramasse sujeira, porque tu acha que isso aqui é uma porcaria, é um cocho, mas tu vem comer aqui, o ordenado tu vem ganhar aqui, isso eu dizia na cara dele e dos outros. Nunca tive medo de empregado, ele fazia as maiores safadezas para mim na minha frente, e tu não tinha o que fazer [...] eu pedi a falência, o sindicato não tomou conhecimento que eu fui a falência, eu tirei as máquinas de lá e trouxe pra cá, eu deixei ronda pago por mim, telefone pago por mim, luz elétrica paga por mim depois de falido, porque eu tenho certeza que meia dúzia deles, como esse que eu te disse que botei na rua, eles botariam fogo se pudessem, porque eles têm ódio de patrão, e não se trata de mim, se trata de qualquer um que leva o nome de patrão. Nós não criamos no Brasil uma mentalidade de que o patrão é amigo do empregado, que um tem que ser amigo do outro, aqui nós criamos uma mentalidade de que um tem que ser inimigo do outro, eu descordo totalmente dessa mentalidade. Eu conheço outras partes do mundo, nunca vi esse tratamento de botar um empregado efetivo dentro da sua fábrica pra fazer tudo que fosse possível pra sabotar" (empresário, entrevista, 2007). 
Com o passar dos anos tem se alterado a dinâmica do controle no espaço de trabalho. As modalidades de ação se intensificam tanto em decorrência das novas tecnologias como em função das novas políticas gestoriais. A esse respeito uma das safristas que já foi empregada de duas fábricas diferentes, uma que se modernizou e outra que nem tanto, compara a ambas: “a fábrica (...) é bem diferente da (...), é um ritmo mais lento, eles têm pouco maquinário lá, trabalham da forma mais antiga, então, não é aquele monte de coisa, a maioria é feita à mão mesmo [...] os encarregados é outra coisa, eles chegam e conversam contigo" (safrista, entrevista, 2007).

As chefias das diferentes fábricas da cidade fazem circular detalhes sobre os seus quadros de funcionários, quer dizer, trocam informações sobre os trabalhadores:

[...] quando o pessoal fez alguma coisa em outra fábrica, a informação chega lá, o pessoal já tá sabendo, e quando tu vai te alistar, a pessoa já te diz, eu sei que tu fez isso, fez aquilo, e espero que tu não faças essas coisas aqui dentro [...] tem linguarudo, chega tudo rápido e para botar fogueira na vida de alguém vão só no telefone e já diz, fulana fez isso, fez aquilo. (safrista, entrevista, 2007).

Os trabalhadores observam essa colaboração entre os empresários e consideramse sem força suficiente para se contrapor a esse poder. Atribuem ao sindicato esse papel, criticando a entidade quando não corresponde a essa função.

[...] o sindicato tinha que ir lá, dá em cima deles. Onde já se viu, as pessoas trabalham e eles tratam as pessoas tipo animal, e ninguém faz nada, tinha que ir lá o sindicato. O que eles fazem lá, quem nunca trabalhou se apavora [...] O sindicato tinha que ir lá, né? [...] as coisas que acontece lá o sindicato não fica sabendo, não tão nem aí (safrista, entrevista, 2007).

Nessa mesma fábrica indicada acima houve uma paralisação em decorrência dos atrasos dos salários. Na ocasião, a empresa entrou em contato com os trabalhadores avisando que não fossem trabalhar, de modo a evitar que o pessoal se juntasse ao sindicato.

[...] nós vimos aquela multidão, até carreteiro eles fizeram lá na frente. Eles queriam que todos funcionários fossem, mas quando a gente viu aquilo ali nós demos de volta [...] não é por não concordar, mas é que o nome da gente fica falado, fulano tava lá, e sai tudo no jornal, colocam depoimento. A minha turma não foi, nós pegamos e demos tudo de volta [...] o chefe tava ali e tava vendo tudo (ex-efetiva, entrevista, 2007).

A participação sindical dos trabalhadores é mínima, mas a valorização da instituição é significativa: “[...] eles têm que tá em cima, porque se não fosse o sindicato, a gente não tinha nem bebedouro na firma, a gente ia tomar água direto das torneiras. Antes tu não tinha copo, tinha que tá botando a boca de baixo da torneira [...] colocaram 
porque eles estavam encima disso aí, isso aí eu acho justo"(safrista, entrevista, 2007). O reconhecimento do sindicato como instância de construção de direitos, não garante, contudo, a participação do trabalhador na instituição.

\section{Sociologia dos conflitos do trabalho}

Considerando as novas dinâmicas de trabalho implementadas no setor conserveiro a partir dos anos 1990, observa-se que a acentuação das formas de controle é uma das geradoras dos conflitos que motivam a ação sindical.

Entre outras dinâmicas de transformação do segmento, verifica-se nos últimos anos que o ramo conserveiro foi capaz de obter um grande aumento de produtividade com redução de trabalhadores. Também, em sintonia com o que há de mais moderno em diferentes partes do mundo, as instituições que compõem essa cadeia produziram muito mais conhecimento do que anteriormente, como evidenciam as pesquisas sobre rastreabilidade $^{20}$, Produção Integrada, Indicação Geográfica, além da própria incorporação das Boas Práticas de Fabricação $(\mathrm{BPF})^{21}$ e do modelo de gestão Análises de Perigos, Pontos Críticos de Controle (APPCC) ${ }^{22}$.

Isso significa que naquilo que não se refere à força de trabalho o setor tem sido bastante inovador, absorvendo novos modelos tecnológicos e de práticas de gestão internacionais.

Antunes (2005) considera que as lutas dos trabalhadores, desde práticas coletivas, como greves e conselhos, até as individualizadas, como absenteísmo e fuga do trabalho, levou o capital a reagir, manifestando seu intuito de retomar patamares de crescimento, mas excluindo as seguridades sociais, quer dizer, "desmantelando o compromisso keynesiano" (Mattoso, 1995) e desarticulando o "embrião de pacto fordista” existente em alguns lugares e setores (Castro; Dedecca, 1998, p.17).

No caso do setor das conservas, as seguridades sociais sempre foram escassas em função da instabilidade da condição de safristas, bem como, da maioria daqueles que trabalham no ramo. O prazo de trabalho como safristas extrapola frequentemente o

\footnotetext{
${ }^{20}$ Conforme a Instrução Normativa $\mathrm{n}^{\circ} .20$, de 27 de setembro de 2001 do Ministério da Agricultura, Pecuária e Abastecimento (MAPA), a rastreabilidade torna-se obrigatória na Produção Integrada de Fruta (PIF), sendo necessária a manutenção de registro de todos os procedimentos. O EAN/UCC-128 é o mais completo código de barra da atualidade.

${ }^{21}$ Cf. sobre as Boas Práticas de Fabricação (BPF) em http://www.anvisa.gov.br.

${ }^{22}$ Cf. Guia do empresário para o sistema APPCC. Série Qualidade e Segurança Alimentar. Sebrae, Rio de Janeiro, 2000.
}

Revista Em Debate (UFSC), Florianópolis, volume 17, p. 127-146, 2017. ISSNe 1980-3532 
limite legal dos seis meses de contrato e, em alguns casos denunciados, quando saem dessa condição, continuam o resto do ano nas empresas sem ter carteira assinada, supostamente como "diaristas".

A desregulamentação do trabalho intensificou ainda mais à informalização e instabilidade no setor, que já era muito grande e aprofundou os níveis de insegurança dos trabalhadores diante da ameaça crescente de desemprego.

Toledo (1997) considera, em relação à flexibilização do trabalho na América Latina, que as contratações não se flexibilizaram mais porque já eram por demais flexibilizadas, sendo o Estado um promotor permanente dessa desregulamentação. $\mathrm{O}$ que no caso das conservas, por exemplo, percebe-se nas Medidas Provisórias do presidente Fernando Henrique (PSDB), que formalizaram as práticas já existentes do Banco de Horas; legalizaram a Participação nos Lucros e Resultados (PLR), bem como, transformou em lei o contrato por safra. Por isso, observa-se que a opção neoliberal levou a um agravamento ainda maior das já precárias condições de trabalho (Mattoso, 1995, p.10).

Conforme Ramalho (1997), mesmo com o movimento de reestruturação produtiva, que tende a intensificar a exploração e reduzir direitos, nos setores modernos, os trabalhadores ainda possuem um poder de pressão sindical, o qual nos demais segmentos encontra-se fragilizado. Para o autor, de modo geral, a reestruturação em andamento nos últimos anos tem significado trabalho informal, insegurança e maior seletividade permitida pelo alto número de mão de obra disponível, situações que os sindicatos têm tido dificuldade de resolver.

Os sindicalistas têm tido dificuldade de lidar com os contextos de alto desemprego, doenças ocupacionais e diminuição da arrecadação sindical. Os trabalhadores estão em desacordo com as condições a que são submetidos no espaço da empresa, mas aceitam-nas porque precisam do emprego. Assim, o desemprego constitui uma forma de controle objetivo e subjetivo, fazendo com que os trabalhadores, muitas vezes, colaborem com a gerência "mais por medo do que por convencimento" (Ramalho, 2004, p.206).

O desemprego opera como "dispositivo coercitivo" (Alves, 2005, p.259) contra as manifestações dos trabalhadores. De acordo com este autor, depois do movimento de reestruturação produtiva, poucos sindicatos preservaram a perspectiva de resistência de classe, a maioria assumiu uma postura defensiva, de negociação e conciliação com capital. No entanto, o sindicato dos trabalhadores das conservas tem criticado essa Revista Em Debate (UFSC), Florianópolis, volume 17, p. 127-146, 2017. ISSNe 1980-3532 
opção, realizando mobilizações e greves. Portanto, apesar dos alcances e ganhos parciais, não se tornaram um sindicato apenas em prol da conciliação, no sentido ao qual se refere Alves (2005).

O STICAP é mais radical em algumas questões e negociador em outras. Apresenta-se como crítico da CUT, considerando que a Central atrelou-se excessivamente aos governos petistas, mas assim mesmo continuou filiado a ela. Pensa que a Cadeia Produtiva das Conservas é um espaço onde se discute apenas interesses empresariais, mas chegou a participar das reuniões da Cadeia durante alguns anos. Afirma serem os empresários do setor conserveiro os que mais concentram poder e exploram os trabalhadores, no entanto, entraram no processo antidumping como apoiadores do setor empresarial no sentido de taxarem a entrada de pêssego de outros países. Criticam o fato da CUT receber recursos do FAT (Fundo de Amparo ao Trabalhador), mas fizeram curso de formação profissional com esses recursos. São contra o Banco de Horas, mas não fizeram consideração contra a Participação nos Lucros adotada por uma das empresas. Acusam as empresas pelo desemprego por acreditar que seria menor se elas reduzissem a jornada, ao mesmo tempo discutem que a "empregabilidade" com ênfase na educação seria a forma para inserção do mercado de trabalho. Isto é, entendendo que ela é de base exclusivamente individual e desconhecendo que a inclusão laboral é fruto também de uma combinação de vários fatores sociais, incluindo aqui a responsabilidade das próprias empresas, do Estado, entre outros atores.

Tais questões revelam as ambiguidades de um tempo em que prática e discurso entrelaçam-se, mas não são sinônimos. Não se pode concordar com Alves (2005), no sentido de dizer que esse sindicato abandonou a postura de antagonismo e enfrentamento que o caracterizava, como se observou no relato do ex-industrial que afirma que nos anos 1980 e meados de 1990, somente estavam dentro da empresa para "anarquizar" (R.O). Mas, faz-se preciso questionar se todas suas ações, como nos disse o presidente do STICAP (entrevista, 2007), são "[...] pela classe, mesmo que contra classe".

Se levado em conta a relação entre luta de classe e a "recuperação das lutas", analisadas por Bernardo (1991) e Alves (2005) ao relacionarem a melhoria nas condições de trabalho com o acirramento dos conflitos, então, considera-se que, se no setor das conservas as condições de trabalho são rudimentares, isso estaria relacionado, em grande medida, às dificuldades apontadas pelos sindicalistas de organização da luta Revista Em Debate (UFSC), Florianópolis, volume 17, p. 127-146, 2017. ISSNe 1980-3532 
nesse segmento (contrato safrista, altas jornadas, perfil feminino da força de trabalho). Ainda, se as mudanças tecnológicas e organizacionais são mais lentas nas conservas, quando comparadas a outros setores de ponta, isso se relaciona com a própria fragilidade das lutas que, em termos comparativos, pressionam em baixa intensidade os empresários.

A partir dos anos 1990, o sindicato dos trabalhadores diversifica suas formas de ação: interage com a esfera política governamental, atua junto a rádios comunitárias, cria o Grupo da LER, entre outros. Como analisou Ramalho (2006) a respeito do momento de reestruturação produtiva, houve uma necessidade de repensar a ação sindical envolvendo-se mais nos debates sobre os rumos do desenvolvimento econômico e social como um todo, participando de outras instâncias da vida política que afetam os trabalhadores.

Para Ramalho (2006, p.85), esse direcionamento significa uma nova forma de resistência e participação sindical, que vai além das greves e dos conflitos no cotidiano fabril. Segundo Ianni (2004), enquanto os capitais globalizam-se e as relações empresariais internacionalizam-se, a classe trabalhadora permanece muitas vezes restrita às localidades e países, um pouco em função de dificuldades objetivas, mas também devido ao comprometimento com certas ideias nacionalistas, as quais o autor considera insustentáveis. É a isso que remete o desligamento do sindicato em relação as suas organizações internacionais, como a UITA (União Internacional dos Trabalhadores da Alimentação), bem como a noção de "soberania nacional" (sindicalista, entrevista, 2007) como um princípio que os sindicalistas consideram necessário ser defendido.

Conforme Cardoso (2004), o movimento dos trabalhadores e as sentenças judiciais ainda são obstáculos à precarização geral das condições de trabalho. No caso da explosão de recursos à justiça na década de 1990, o autor relaciona isso ao enfraquecimento dos sindicatos e à diminuição do poder de fiscalização do Estado, pois, quando este é forte por si mesmo, faz valer os direitos. Enquanto a justiça do trabalho é mais frequentemente acionada, vê-se reduzir os movimentos de greve, como resultado de uma retração da ação coletiva em relação ao recurso individual.

Observou-se junto aos sindicalistas que, embora sendo mais distante do STICAP, a categoria das conservas foi a que moveu o maior número de ações trabalhistas na década de 1980 e 1990. Concordando com Cardoso (2004, p.179), tratase de uma "flexibilização a frio do mercado de trabalhos pelos empregadores, via ilegalidade". O fato do setor conserveiro frequentemente recorrer à justiça, indica não Revista Em Debate (UFSC), Florianópolis, volume 17, p. 127-146, 2017. ISSNe 1980-3532 
apenas que os empresários não cumprem as leis, mas também o fato de que a ação coletiva, politizada, ficou em segundo lugar na busca por resolução dos conflitos. Anteriormente, os processos judiciais ainda eram ações coletivas movidas pelo sindicato, mas desde fins de 1990 são muito mais frequentes as ações individuais, o que traz o urgente problema a ser pensado que é a da individualização dos conflitos do trabalho.

\section{Considerações finais}

A indústria conserveira de Pelotas (RS) e região, desde os anos 1990 se modernizou de um forma sem precedentes no segmento. As ações resultaram na implementação de novas tecnologias e práticas gestoriais. Todavia, e esse é o problema social e sociológico central, essa modernização não se verificou do ponto de vista do trabalho. Tal constatação produziu uma perversa equação que tem deixado o sindicato perplexo: tecnologia moderna + gestão eficiente = degradação do trabalho.

O conservadorismo dos empresários desse setor - que emerge sem maiores encobrimentos nos anos 1990 - se expressa por uma história de repressão através de ameaças, de demissão de diretores sindicais, de repressão a greves com polícia e de violência direcionada àqueles que contestam a gestão do trabalho.

Verificou-se que houve no setor conserveiro uma reestruturação heterogênea no que se refere aos processos produtivos e uma intensificação da histórica precariedade das condições e relações de trabalho, agravadas pelo desemprego. Embora com dificuldades de organização sindical, os trabalhadores não andam passivamente por esses processos, guardam a criatividade de fazer desse universo também um locus de expressão de suas rebeldias.

É curioso observar que a região de Pelotas, observada nesse trabalho, é responsável pela produção da maior parte das compotas de pêssego consumidas no Brasil. Trata-se do beneficiamento de um fruta dourada como ouro e que se torna muito doce, quando se adiciona a calda às latas de compotas. A doçura da fruta, todavia, é contrastada pelo amargo do universo laboral que a produz.

\section{Referências}

ALVES, Giovanni $O$ novo(e precário)mundo do trabalho: Reestruturação produtiva e crise do sindicalismo. São Paulo: Boitempo, 2005. 
ANTUNES, Ricardo. Os Sentidos do trabalho. Ensaio sobre a afirmação e a negação do trabalho. São Paulo: Boitempo, 2005.

BERNARDO, João. Democracia totalitária: teoria e prática da empresa. São Paulo: Cortez, 2004.

BERNARDO, João. Economia dos conflitos sociais. São Paulo: Cortez, 1991.

CARDOSO, Adalberto. A década neoliberal e a crise dos sindicatos no Brasil. São Paulo: Boitempo, 2004.

DEDECCA et.al. Flexibilidade e precarização: os tempos mais duros. In: DEDECCA, Claudio; CASTRO, Nadya (Org.). A ocupação na América Latina: Tempos mais duros. São Paulo - Rio de Janeiro, 1998. (Série II Congresso Latino-americano de sociologia do trabalho).

IAMAMOTO, Marilda. Trabalho e indivíduo social: um estudo sobre a condição operária na agroindústria canavieira paulista. São Paulo: Cortez, 2001.

IANNI, Octavio. A era do globalismo. Rio de Janeiro: Civilização brasileira, 2004.

MATTOSO, Jorge. A desordem do trabalho. São Paulo: Página Aberta, 1995.

RAMALHO, José Ricardo. Dinâmica sociopolitícas em novos territórios produtivos. In: . (Org). Dossiê: Novos espaços industriais e desenvolvimento regional. Cadernos CRH. 19, n.46 - jan./abr. 2006.

Novas fábricas, velhas práticas: relações trabalhistas e sindicais na indústria automobilística. In: LIMA, Jacob Carlos (Org.). Dossiê: Trabalho e novas sociabilidades.v.17, n.41-Maio./ Ago.2004.

RAMALHO, José Ricardo. Precarização do trabalho e impasses da organização coletiva no Brasil. In: ANTUNES, Ricardo (Org.). Neoliberalismo, trabalho e sindicatos: Reestruturação produtiva no Brasil e na Inglaterra. São Paulo: Boitempo, 1997.

TOLEDO, Enrique. La flexibilidad del trabajo en América Latina. Revista Latinoamericana de Estudos do trabalho, ano 3, n5, 1997, pp.129-157. 